\title{
Conflict Resolution Behavior Questionnaire: New Evidences of Validity
}

\author{
Patrícia Nunes da Fonseca ${ }^{\top}$ \\ Nájila Bianca Campos Freitas ${ }^{1}$ \\ Ricardo Neves Couto ${ }^{1}$ \\ Jérssia Laís Fonseca dos Santos ${ }^{1}$ \\ Viviany Silva Araújo Pessoa ${ }^{T}$ \\ ${ }^{1}$ Universidade Federal da Paraíba, João Pessoa, Brasil
}

\begin{abstract}
This study aimed to investigate new evidence of internal and external validity of the Conflict Resolution Behavior Questionnaire (CRBQ) for the context of the state of Paraíba, Brazil. A total of 252 people participated this study, being in a marital relationship, with an average age of 38.3 years $(\mathrm{SD}=10.87)$, the majority of whom were married $(70 \%)$ and female $(57.1 \%)$. An Exploratory Factorial Analysis of the CRBQ pointed an adequate structure with three factors (agreement, avoidance, and attack), with alphas ranging from 0.75 to 0.77 , which were related to personality traits. In this direction, the results are discussed, in the light of the specialized literature, and it is concluded that the psychometric adequacy of the CRBQ expands the evidence of validity and can be used in future studies in the Brazilian context by researchers and those interested in the subject.

Keywords: strategies; conflicts; validity.
\end{abstract}

Questionário de Comportamento de Resolução de Conflitos: Novas Evidências de Validade

\begin{abstract}
Resumo
Esse estudo objetivou investigar novas evidências de validade interna e externa do Questionário de Comportamento de Resolução de Conflitos (Conflict Resolution Behavior Questionnaire - CRBQ) para o contexto brasileiro paraibano. Participaram 252 pessoas que indicaram estar em um relacionamento conjugal, com média de idade de 38,3 anos (DP=10,87), sendo a maioria casada $(70 \%)$ e do sexo feminino $(57,1 \%)$. Uma análise fatorial exploratória do CRBQ apontou uma estrutura adequada com três fatores (acordo, evitação e ataque), com alfas variando de 0,75 até 0,77 , que apresentaram relações com os traços de personalidade. Nessa direção, discutem-se, à luz da literatura especializada, os resultados e conclui-se que a adequação psicométrica da medida do CRBQ amplia as evidências de validade, podendo ser utilizada em pesquisas no contexto brasileiro por pesquisadores e interessados na temática.

Palavras-chave: estratégias, conflitos, validade.
\end{abstract}

\section{Cuestionario de Conductas de Resolución de Conflictos: Nuevas Evidencias de Validez}

\section{Resumen}

Este estudio tuvo como objetivo investigar nuevas evidencias de validez interna y externa del Cuestionario de Conducta de Resolución de Conflictos (CCRC) para el contexto de la provincia brasileña de Paraíba. Participaron un total de 252 personas en relación conyugal, con una edad media de 38,3 años $(\mathrm{DS}=10,87)$, la mayoría casadas $(70 \%)$ y mujeres $(57,1 \%)$. Un Análisis Factorial Exploratorio del CCRC señaló una estructura adecuada con tres factores (acuerdo, evasión y ataque), con alfas variando entre 0,75 y 0,77 , que se relacionan con rasgos de personalidad. En esta dirección, se discuten los resultados, a la luz de la literatura especializada, y se concluye que la adecuación psicométrica de la medida CCRC amplía la evidencia de validez del instrumento y puede ser utilizado en futuros estudios en el contexto brasileño por investigadores e interesados en el tema. Palabras clave: estrategias; conflictos; duración.

\section{Introduction}

Romantic relationships occupy a relevant place in the lives of individuals, who have basic needs to belong to a group or someone, to be accepted and cared for, to love and be loved (Van de Bongardt, Yu, Dekovic, \& Meeus, 2015). When it comes to marital relationships, it is noted that life as a couple is marked by a period of changes and adaptations, since both spouses need to learn to deal with each other's personal beliefs, values, and habits (Bolze, Schmidt, Crepaldi, \& Vieira, 2013). Thus, during this process of adaptation and maturation, conflict situations may arise.

Marital conflicts occur for several reasons, such as incompatibility of interests, opinions, personal goals, children's education, leisure time for the couple, finances (Delatorre, 2015), and the personality of each spouse (Bolze et al., 2013). However, depending on the outcome of the conflicting situations experienced by couples, such conflicts can be constructive or 
destructive. Occasionally, even in healthy and satisfying conjugal relationships, conflicts can arise (Bolze et al., 2013; Gottman \& Notarius, 2000).

The conflict can be understood as a multidimensional phenomenon, which involves (1) the reasons that trigger it; (2) the frequency with which conflicting situations occur; (3) the intensity of the discussions; and (4) the resolution strategies adopted by couples (Benetti, 2006; Fellows, Chiu, Hill, \& Hawkins; 2015). Thus, the present study was limited to studying marital conflict resolution strategies, which refer to the behaviors used by spouses to manage their disagreements (Delatorre, Scheeren, \& Wagner, 2017).

Some couples deal with everyday disagreements in a peaceful way, using dialogue, negotiations; while others tend to fight, ignore, and/or hold resentments, causing conflicts to return with greater force with each new impasse. In this perspective, marital conflict strategies can be constructive or destructive (Gottman, 1994): the former have an emotional factor that seeks to preserve positive affects, being related to behaviors of negotiating, agreeing with, and validating of points of view, while destructive strategies stimulate negative affects, through hostility and detachment, reflected in behaviors of blaming, avoiding, and being verbally and physically aggressive (Flora \& Segrin, 2015; Gottman, 1994; Kim et al., 2015).

Marital conflict resolution strategies have been researched for more than two decades and studies have pointed out that the ability to use such strategies in an appropriate manner has important implications for the marital relationship (Canary, Cunningham, \& Cody, 1988; Costa, Cenci, \& Mosmann, 2016; Delattorre et al., 2017; Gottman, 1994; Greeff \& Bruyne, 2000). The use of more effective (constructive) strategies, for example, is related to higher levels of marital quality, maintaining a more lasting relationship, and decreasing the possibility of marital separation and divorce (Delatorre et al., 2017; Sierau \& Herzberg, 2012).

In the same direction, Costa and Mosmann (2015) point out that couples who use constructive strategies to resolve their conflicts tend to have higher levels of marital satisfaction, which reinforces the alliance between the couple and strengthens the relationship. In contrast, the use of destructive strategies provokes feelings of hurt and revenge, resulting in greater marital dissatisfaction, which can culminate in constant fights or marital separation. Therefore, it is noted the importance of developing studies on conflict resolution strategies, since daily disagreements between couples are not likely to be avoided, but the way they deal with such situations can have an impact on their stability or lead to the dissolution of conjugal unions.

From this perspective, it is also important to consider the personality of each spouse, since these traits can predict or explain behaviors (Feist, Feist, \& Roberts, 2015). It is in this direction that this research considers personality traits as a variable that relates to conflict resolution behaviors.

To understand the personality structure, the Big Five Personality Traits (BFPT), has been widely highlighted in international and Brazilian literature. In the Brazilian context (Nunes, Hutz, \& Nunes, 2010), although there are some variations, commonly the five personality traits are described as follows: (1) Openness to experience, describing behaviors of people who wish and want to live new experiences; (2) Conscientiousness, concerning people who are prudent, responsible, and knowledgeable about their duties; (3) Extroversion, referring to activity and energy, expressiveness and positive emotions; (4) Amiability, corresponding to the quality of interpersonal relationships, that is, how helpful and altruistic a person is with others; and (5) Neuroticism, referring to emotional instability or experimentation with negative affects.

Such personality traits have been related to marital conflicts, as well as behaviors for dealing with these conflicts (Iveniuk, Waite, Laumann, Mcclintock, \& Tiedt, 2014; McNulty, 2008; Ozer \& Benet-Martínez, 2006). Iveniuk et al. (2014), for example, found that when husbands had higher scores in neuroticism and extroversion, their wives reported higher levels of conflict. Similarly, McNulty (2008) noted that spouses who score higher on neuroticism are more likely to make destructive criticism and be hostile towards their partners. In this perspective, these partners tend to be unhappy in their marriages, due to the magnitude of the negative affects.

In addition, conflict resolution strategies can be effective tools in strengthening positive skills and preventing hostile and aggressive behavior in the marital relationship. Thus, considering the instruments to measure such strategies is essential to assess the couple's dynamics, identify individual conflict management skills, and know some beliefs that collaborate to maintain behaviors that reinforce the adoption of inappropriate practices, such as verbal and physical aggression (Bonache, Ramírez-Santana, \& GonzalezMendez, 2016).

That said, it is worth highlighting some instruments found in the literature, which aim to assess the 
strategies used by couples in conflict resolution. Among them, we can mention the Marital Conflict Scale, elaborated by Gottman (1994), assessing couples according to the communication patterns between themselves during conflicts; the Episode-Specific Conflict Tactics Scale (Canary et al., 1988), which was designed to assess integrative, distributive, and avoidance strategies; and the Romantic Partner Conflict Scale (Zacchilli, Hendrick, \& Hendrick, 2009), designed to assess the communication between the couple, since the authors consider it as a type of fundamental strategy in resolving conflicts.

In relation to the Brazilian context, some measures that were validated for the Brazilian context are highlighted, as is the case of the Revised Conflict Tactics Scale, developed by Straus, Hamby, BoneyMcCoy, \& Sugarman's, 1996), validated by Alexandra and Figueiredo (2006), which focuses on abusive relationships, assessing behaviors such as physical aggression and sexual coercion. The Conflict Resolution Styles Inventory proposed by Kurdek (1994) and validated by Delatorre et al. (2017) is also noteworthy, assessing the positive resolution, withdrawal, submission, and involvement in the conflict dimensions.

However, none of the aforementioned instruments have the advantage of being a relatively brief measure that covers a wide range of strategies that can be used by spouses to resolve conflicts. In this direction, the Conflict Resolution Behavior Questionnaire, developed by Rubenstein and Feldman (1993), adapted and validated for the Brazilian context by Delatorre and Wagner (2015), is emphasized.

Initially, the Conflict Resolution Behavior Questionnaire (CRBQ) was designed to assess conflict resolution strategies in a sample of adolescents. For its construction, fourteen items were developed based on a questionnaire prepared by Rands, Levinger and Mellinger (1981), which assessed strategies for resolving and perceiving conflict in couples, with eight more items developed by the researchers. In this sense, although the original CRBQ was designed for use with adolescents, some of these items were constructed with a view to the marital relationship. In view of this, Reese-Weber and Bartle-Haring (1998) adapted the instrument for use with couples.

Thus, the final version of the marital context CRBQ, corresponds to a questionnaire of twenty-two items, divided into three dimensions: (1) attack, corresponding to hostile, authoritarian, or psychological and physical aggressions; (2) avoidance, referring to indifference or withdrawal from the conflict; and (3) agreement, understanding the other spouse's point of view or attempting to resolve the problem through negotiation.

Reese-Weber and Bartle-Haring (1998) start from the premise that misunderstandings and incompatible goals are inevitable in relationships. Thus, they believe that conflicts can be constructive when spouses are engaged in seeking solutions to disagreements, so that they reach an agreement. In contrast, destructive solutions trigger hostility and neglect in the face of conflicts.

Therefore, the CRBQ is a measure that presents the following criteria: (1) it assesses the frequency with which spouses use certain strategies of conflict resolution; (2) its items represent various behaviors adopted by spouses in the face of conflict resolution (e.g., reasoning, listening, fighting back, keeping their feelings to themselves, running away from the problem) and; (3) it considers the strategies from two dimensions: constructive (when it promotes a satisfactory marital quality) or destructive (when it threatens or harms the relationship).

The study by Delatorre and Wagner (2015) in Brazil allowed to find initial evidence of validity based on exploratory analysis, internal consistency and the relationship between its dimensions and marital quality. However, despite the stability of the structure with three dimensions, items " 09 " and " 11 " saturate in different dimensions from the original instrument. Because of this, they proposed a reformulated version of the CRBQ to be applied in future studies, to resolve problems identified in some of the items.

It is emphasized that the validity of an instrument is understood as the ability of an instrument to accurately measure the phenomenon to be studied (Ambiel \& Carvalho, 2017). Therefore, it is understood that further studies are necessary, as they will make it possible to confirm and/or add evidence of validity for the CRBQ. As pointed out by Urbina (2007), a wide source of evidence of validity is needed to consider a valid instrument in a given context. Therefore, this study aimed to investigate new evidence of internal and external validity of the Conflict Resolution Behavior Questionnaire for the context of the state Paraíba, Brazil.

\section{Method}

\section{Participants}

A convenience sample (not probabilistic) was formed, composed of 252 people from the general 
population of the capital of the state of Paraíba (Brazil), of which 176 (70\%) were married and $76(30 \%)$ living together with their partners, with an average age of 38.3 (between 20 and 66 years old, SD $=10.87$ ) and with complete Higher Education (39.3\%). Most of them were women $(144 ; 57.1 \%)$, with children $(62.7 \%)$, and who had been in a relationship for more than 10 years $(50.8 \%)$.

\section{Instruments}

Conflict Resolution Behavior Questionnaire (CRBQ). Originally constructed in English by Rubenstein and Feldman (1993), it seeks to assess the frequency with which certain behaviors are used to resolve marital conflicts. The instrument consists of 22 items and was adapted and validated for the Brazilian context by Delatorre and Wagner (2015), maintaining the original structure with three dimensions: avoidance (e.g., item 7 "I sulk and keep my feelings to myself"), attack (e.g., item 15 "I say or do something to hurt my spouse") and agreement (e.g., item 6 "I listen to what the other is saying and try to understand their point"), which are answered on a Likert scale, varying from 1 (Never) to 5 (Always). The adapted version showed acceptable Cronbach alphas, ranging from 0.79 (agreement), 0.74 (attack) and 0.69 (avoidance; Delatorre \& Wagner, 2015).

Big Five Personality Traits Inventory (BFPTI). A measure prepared by John, Donahue, and Kentle (1991), consisting of 44 items. Adapted for Brazil (Andrade, 2008), its factors have alphas ranging from 0.68 (Openness and Conscientiousness) to 0.76 (Extroversion). A reduced version will be used, consisting of 20 items, choosing the four with the highest factor loads in the study by Schmitt et al. (2007). The items are structured in sentences (e.g., Likes to cooperate with others; Is kind and considerate towards others), and the individual must indicate how they perceive themselves (I see myself as someone who ...), using a Likert scale of five points, ranging from (1) "totally disagree to (5)" totally agree".

Sociodemographic issues. Composed of questions about age, sex, marital status (married or living together), time together, and whether they had children.

\section{Procedure}

At first, the project was submitted to Plataforma Brasil (Brazil Platform) to be assessed by the Human Research Ethics Committee, being approved, according to the Certificado de Apresentação para Apreciação Ética
(CAAE, Presentation Certificate for Ethical Appreciation) protocol number 53707116.2.0000.5188. For the application, we opted for public places (e.g., public squares, universities) and, although the approach was made collectively, the responses were individual. When approached, people were invited to participate in the study and informed about the objective of the research, the guarantee of anonymity of responses and the possibility of leaving the study at any time, without any penalties. Then, they signed the Informed Consent Form (ICF), which was based on the current ethical precepts for conducting research with human beings, defended by Resolutions 466/12 and 510/16 of the National Health Council. The application lasted 15 minutes on average.

\section{Data analysis}

Data were analyzed using the statistical Factor 9.2 and the R software (version 3.3.2; R Development Core Team, 2015). With the former, exploratory factor analysis was performed, using Hull methods and parallel analysis, in addition to Cronbach's alpha coefficient $(\alpha)$ and homogeneity; with the latter, descriptive analyzes were carried out to characterize the sample and correlate the measure with personality traits.

\section{Results}

\section{Exploratory Factor Analysis}

Initially, an exploratory factor analysis of the CRBQ was performed, using the Unweighted Least Squares (ULS) extraction method, supported by satisfactory Kaiser-Meyer-Olkin $(\mathrm{KMO})$ indices $=0.83$, and Bartlett's sphericity test $=1632.5$ (231); $\mathrm{p}<0.001$. Therefore, it was possible to observe that, according to the Hull method, the data fit into a structure with three factors, similar to the version validated by Delatorre and Wagner (2015). Then, a Parallel Analysis was carried out, which randomized 5000 databases with similar characteristics and provided averages of eigenvalues, according to the Horn criterion (1965), there were three real eigenvalues $(5.16 ; 2.48 ; 2.15$; 1.11) larger than the random ones $(1.57 ; 1.47 ; 1.39$; 1.33). Soon, the extraction of three factors was determined, with Promin rotation (oblique). The results are described in Table 1.

According to the results presented in Table 1, the three factors together accounted for $44.51 \%$ of the total variance, and none of the 22 items presented 
Table 1.

Factor Structure of the Conflict Resolution Behavior Questionnaire (CRBQ)

\begin{tabular}{|c|c|c|c|c|}
\hline \multirow{2}{*}{ Items } & \multicolumn{3}{|c|}{ Factors } & \multirow{2}{*}{$h^{2}$} \\
\hline & I & II & III & \\
\hline 1. I try to avoid talking about it & $0.33^{*}$ & 0.06 & -0.03 & 0.09 \\
\hline 2. I get terribly angry and start yelling & -0.07 & -0.14 & $0.50 *$ & 0.29 \\
\hline 3. I try to reason it in my mind & 0.03 & $0.62 *$ & -0.04 & 0.39 \\
\hline 4. I act sarcastically & $0.45^{*}$ & -0.13 & 0.06 & 0.29 \\
\hline 5. I try to calm things down & 0.06 & $0.61 *$ & -0.17 & 0.44 \\
\hline 6. I listen to what the other is saying and try to understand their point & -0.07 & $0.65^{*}$ & -0.05 & 0.49 \\
\hline 7. I sulk and keep my feelings to myself & $0.70^{*}$ & -0.02 & -0.27 & 0.43 \\
\hline 8. I try to reach an agreement & -0.02 & $0.63^{*}$ & 0.11 & 0.37 \\
\hline $\begin{array}{l}\text { 9. I get cold and distant or with an "I don't care" attitude towards the } \\
\text { other }\end{array}$ & $0.72 *$ & -0.11 & -0.06 & 0.56 \\
\hline 10. I sulk and stay away from my partner & $0.60^{*}$ & -0.20 & 0.12 & 0.59 \\
\hline 11. I lose control and say everything I am feeling & -0.22 & 0.03 & $0.80^{*}$ & 0.55 \\
\hline 12. The more I speak, the angrier I get & 0.07 & 0.03 & $0.75^{*}$ & 0.60 \\
\hline 13. I remain angry for a long time & 0.27 & -0.07 & $0.52^{*}$ & 0.49 \\
\hline $\begin{array}{l}\text { 14. I get angry and throw whatever is in front of me at the other } \\
\text { person }\end{array}$ & 0.06 & 0.06 & $0.49 *$ & 0.25 \\
\hline 15. I say or do something to hurt my spouse & 0.01 & -0.02 & $0.57^{*}$ & 0.33 \\
\hline 16. I try to be alone & $0.68^{*}$ & 0.13 & 0.07 & 0.44 \\
\hline 17. I watch TV, read a book, or try to get distracted by other things & $0.52 *$ & 0.26 & 0.11 & 0.26 \\
\hline 18. I tell myself that the problem is not important & 0.25 & 0.28 & 0.20 & 0.12 \\
\hline 19. I try to be in a good mood and make fun of it & 0.16 & $0.57^{*}$ & -0.01 & 0.28 \\
\hline 20. I talk to a friend or family member about how I feel & 0.01 & 0.22 & $0.33^{*}$ & 0.11 \\
\hline 21. I apologize to my spouse & -0.14 & $0.54 *$ & 0.11 & 0.33 \\
\hline 22. I retaliate in the same way as my spouse: "I return the favor" & -0.01 & -0.12 & $0.51 *$ & 0.31 \\
\hline Quantity of items & 07 & 06 & 08 & \\
\hline$\%$ of explained variance & 23.48 & 11.26 & 9.77 & \\
\hline Self-value & 5.16 & 2.48 & 2.15 & \\
\hline Cronbach's $\alpha$ & 0.75 & 0.75 & 0.77 & \\
\hline Homogeneity & 0.31 & 0.35 & 0.30 & \\
\hline
\end{tabular}

Note. Factors: I - Avoidance, II - Agreement, III - Attack. (*) Factor load considered satisfactory for the factor $>|0.30|$.

cross loadings in more than one factor. From the cutoff point used in the literature ( $>0.30$; Pasquali, 2011), item 18 (I tell myself that the problem is not important) was excluded for it did not reach the minimum factor load in any of the factors. Therefore, the final structure was composed of 21 items, distributed among the three retained factors.

Factor I, defined as avoidance, had an eigenvalue of 5.16 , explaining $23.48 \%$ of the total variance, with factor loads ranging from 0.33 (Item 01 . I try to avoid talking about it) to 0.72 (Item 09. I get cold and distant or with an "I don't care" attitude towards the other). Cronbach's alpha was 0.75 and homogeneity, measured by the mean inter-item correlation, was 0.31 .

Factor II, called agreement, whose self-value was equal to 2.48 , explained $11.26 \%$ of the total variance, presented factor loads ranging from 0.54 (Item 21. I apologize to the other) to 0.65 (Item 06. I listen to what 
the other is saying and try to understand). Cronbach's alpha was 0.75 and homogeneity was 0.35 .

Finally, Factor III, attack, had its self-value equal to 2.15 and explained $9.77 \%$ of the total variance, with factor loads ranging from 0.33 (Item 20. I talk to a friend or family member about how I feel) to 0.80 (Item 11. I lose control and say everything I am feeling). Cronbach's alpha was 0.77 and homogeneity was 0.30. In summary, these results indicate new internal evidence for the measure, based on the factorial validity and precision of the scale, which presents a general Cronbach's alpha equal to 0.83 .

In addition, Pearson (r) correlations were carried out between the three factors of the measure and the personality traits, in order to gather evidence of external validity, since it was sought to assess the extent to which these psychological processes with related, but distinct, dimensions presented correlation indices (Nunes \& Primi, 2010).

According to Table 2, the Attack factor showed a statistically significant and negative correlation with amiability $(\mathrm{r}=-0.24 ; \mathrm{p}<0.001)$ and positive with neuroticism $(r=0.36 ; p<0.001)$. As for the Agreement factor, it presented correlations with all personality traits, however, the items whose indices are greater than 0.20 should be noted, suggesting evidence of external validity (Nunes \& Primi, 2010), thus, highlighting the relationship with conscientiousness $(r=0.21$; $<0.001)$ and amiability $(\mathrm{r}=-0.23 ; \mathrm{p}<0.001)$. Finally, the Avoidance factor showed a negative correlation with amiability $(r=-0.21 ; \mathrm{p}<0.001)$.

\section{Discussion}

With the results presented, new psychometric evidences of the CRBQ are made available, gathering psychometric criteria of validity and reliability. With the exploratory factor analysis, using the Hull method and the parallel analysis, three factors (agreement, avoidance, and attack) were found, corroborating the original study (Reese-Weber \& Bartle-Haring, 1998) in the same way as the adaptation carried out in the southern region of Brazil (Delatorre \& Wagner, 2015). It should also be noted that the structure of three factors explained $44.51 \%$ of the variance and demonstrated an equally satisfactory precision, with Cronbach's alpha = 0.83 (Cohen, Swerdlik, \& Sturman, 2014).

Comparing the results found by Delatorre and Wagner (2015), the present study showed changes in three items that had different dimensions. Thus, item 4, which in the original questionnaire is "Get sarcastic", belonged to the attack factor, but saturated in the avoidance factor, this can be justified on the grounds that sarcasm can be used to soften or depart the tension caused by the conflict (Fincham, 2003).

Item 13, "Stay mad for a long time", belonged to the avoidance factor, but saturated in the attack factor, as well as in the original version. Such result may have occurred due to the semantics, remaining angry can be represented by hostile and/or aggressive behaviors

Finally, item 19 ("Try to be funny and make light of it") belonged to the avoidance factor, both in the original study and in the Brazilian adaptation, however, it saturated in the agreement factor in this study. According to these authors, the expression "make light of" refers to a situation in which the individual underestimates or disdains the reason for the conflict. Therefore, good mood in the Brazilian context can be used to reduce the tension resulting from the conflict, leading to well-being (Ogolsky, Monk, Rice, Theisen, \& Maniotes 2017).

Therefore, item 18, which in the original version is "Tell yourself the problem is not important", belongs to the avoidance factor, but, in the present study it was excluded for it did not reach the minimum factor load in any of its factors, which may be justified due to the lack of clarity of the item, leading to a misunderstanding of what the item actually referred to.

Table 2.

Correlates between conflict resolution strategy factors and personality traits

\begin{tabular}{cccccc}
\hline Factors & AE & C & E & A & N \\
\hline Attack & 0.02 & -0.06 & 0.03 & $-0.24^{*}$ & $0.36^{*}$ \\
Agreement & $0.16^{*}$ & $0.21^{*}$ & $0.17^{*}$ & $0.23^{*}$ & $-0.18^{*}$ \\
Avoidance & -0.02 & -0.07 & -0.05 & $-0.21^{*}$ & 0.05 \\
\hline
\end{tabular}

Note. ${ }^{*} p<0.001 . \mathrm{OE}=$ Openness to experience; $\mathrm{C}=$ Conscientiousness; $\mathrm{E}=$ Extroversion; $\mathrm{A}=$ Amiability; $\mathrm{N}=\mathrm{Neuroticism}$. 
In addition to the evidence of internal validity of the CRBQ, correlations were observed between the factors of the measure and the personality traits. The indices above 0.20 are highlighted and are statistically significant, which suggest external validity between the related constructs (Nunes \& Primi, 2010; Peixoto \& Ferreira-Rodrigues, 2019).

As seen in the results, the people who had higher scores on the neuroticism personality trait were the ones who most used the attack strategy in conflict resolution, which suggests that such people have an emotional instability that does not allow them to assess the situation in any other way, only from their own points of view (Nunes et al., 2010). For this, they adopt intimidating and authoritarian behaviors towards the other person involved in the fray, showing no respect for the spouse, nor maintaining a harmonious relationship. Similarly, individuals with lower scores on the friendliness trait seemed to adopt attack and avoidance strategies as they behave aggressively, withdrawing and showing total indifference towards the other party (Reese-Weber \& Bartle-Haring, 1998). Unlike individuals who adopt agreement-type conflict resolution strategies, who present themselves in a cordial, kind, respectful way, they are concerned with maintaining the relationship and considering the opinion and interests of the other person (Delatorre \& Wagner, 2015), which goes against people with higher neuroticism scores.

Finally, as shown by the results of the correlation, there are evidences of external validity for the measure, although, not convergent evidences, since they would have to be above 0.50 , and be related constructs. In the present case, the traits are related insofar as they are predictive variables of behavior, but they are hierarchically distinct, so, in these situations, the quoted reference points to acceptable values between 0.20 and 0.50 , which demonstrates the relevance of the results.

In view of this, it is believed that the objective of the present study has been achieved, since was intended to investigate new evidence of internal and external validity of the Conflict Resolution Behavior Questionnaire for the context of the state of Paraíba, Brazil. It is noteworthy that, despite being initially validated for the context of the southern region of the country (Delatorre \& Wagner, 2015), the present study brings new evidence of factorial validity and precision indices (Cronbach's alpha) when compared to another study in the northeastern region of Brazil, therefore, differing according to culture, customs, and socioeconomic situation.

Although the objectives have been achieved, the results of this study must be interpreted in the context of its limitations. In this sense, it is highlighted that the sample was non-probabilistic (convenience) and with a small size, and cannot be considered a representative sample, that is, it is impossible to generalize the results beyond the purpose of the study. Another aspect refers to the type of self-report measure (pencil and paper) and this can lead the individual to give socially acceptable responses (social desirability).

Although the study has presented such limitations, this does not invalidate or disparage the results, given that the CRBQ instrument presented good adjustment rates for the sample, being a reliable measure. Finally, expanding the scope of understanding of marital conflict resolution strategies, it will be important to be aware about the relationship between the types of CRBQ strategies with other constructs, such as marital relationships (Bolze, Schmidt, Böing, \& Crepaldi, 2017), human values (Gunkel, Schlaegel, \& Taras, 2016), and dating violence (Bonache, Ramírez-Santana, \& Gonzalez-Mendez, 2016), facts that would provide evidence of external validity and criteria.

Specially about the CRBQ instrument, it is also suggested to understand the complementary evidence of psychometric adequacy of this measure, such as assessing its temporal stability (test-retest), and to know the evidence of its convergent and discriminant validity. In addition, with other independent samples, confirmatory factor analyzes are suggested, which may also include alternative models, to further refine the scale structure in the Brazilian scenario.

Finally, it is understood the importance of studying this theme, primarily due to the high number of divorces in Brazil, in which individuals, for not having constructive strategies in the management and resolution of marital and family conflicts, immediately resort to the most radical solution, without an understanding of the reasons that generated the conflict and the different possibilities for resolution.

Therefore, the instrument presented here can help researchers and clinical psychologists to better understand the strategies used by couples in the face of conflict and, thus, plan intervention proposals that help spouses to understand the behaviors of the other person in the relationship and to identify the couple's potentiality to the necessary changes in the resolution of marital conflicts. 


\section{References}

Alexandra, C., \& Figueiredo, B. (2006). Versão portuguesa das "Escalas de Táticas de Conflito Revisadas": estudo de validação. Psicologia: Teoria e Prática, 8(1), 14-39.

Ambiel, R. A. M., \& Carvalho, L. F. (2017). Definições e papel das evidências de validade baseadas na estrutura interna em psicologia, In: Damásio, B. F. e Borsa, J. C. (Orgs.). Manual de Desenvolvimento de Instrumentos Psicológicos. São Paulo: Ed. Vetor. p. 85-100.

Andrade, J. M. (2008). Evidências de validade do Inventário dos Cinco Grandes Fatores de Personalidade para o Brasil. Tese de Doutorado. Departamento de Psicologia, Universidade de Brasília, DF.

Benetti, S. P. C. (2006). Conflito conjugal: Impacto no desenvolvimento psicológico da criança e do adolescente. Psicologia: Reflexão e Crítica, 19(2), 261-268. Doi: 10.1590/S0102- 79722006000200012

Bolze, S. D. A., Schmidt, B., Böing, E., \& Crepaldi, M. A. (2017). Conflitos Conjugais e Parentais em Famílias com Crianças: Características e Estratégias de Resolução. Paidéia (Ribeirão Preto), 27(1), 457465. Doi:10.1590/1982-432727s1201711.

Bolze, S. DA. A., Crepaldi, M. A., Schmidt, B., \& Vieira, M. L. (2013). Relacionamento Conjugal e Táticas de Resolução de Conflito entre Casais. Actualidades en psicología, 27(114), 71-85.

Bonache, H., Gonzalez-Mendez, R., \& Krahé, B. (2017). Romantic Attachment, Conflict Resolution Styles, and Teen Dating Violence Victimization. Journal of Youth and Adolescence, 46, 1905-1917. doi:10.1007/ s10964-017-0635-2.

Bonache, H., Ramírez-Santana, G., \& Gonzalez-Mendez, R. (2016). Conflict resolution styles and teen dating violence. International Journal of Clinical and Health Psychology, 16(3), 276-286. doi:10.1016/j.ijchp.2016.03.003.

Canary, D. J., Cunningham, E. M., \& Cody, M. J. (1988). Goal types, gender, and locus of control in managing interpersonal conflict. Communication Research, 15(1), 426-446.

Cohen, R. J., Swerdlik, M. E., \& Sturman, E. D. (2014). Testagem e Avaliação Psicológica: Introdução a Testes e Medidas. ( $8^{\circ}$ ed) São Paulo: AMGH
Costa, C. B., Cenci, C. M. B., \& Mosmann, C. P. (2016). Conflito Conjugal e Estratégias de Resolução: Uma Revisão Sistemática da Literatura. Temas em Psicologia, 24(1), 325-338. doi: 10.9788/ TP2016.1-22.

Costa, C. B, \& Mosmann, C. P. (2015). Estratégias de resolução dos conflitos conjugais: percepções de um grupo focal. Psico, 46(4), 472-482. doi. org/10.15448/1980-8623.2015.4.20606

Delatorre, M. Z. (2015). Conflito conjugal: evidências de validade do Conflict Resolution Behavior Questionnaire (CRBQ) e estilos de resolução de conflitos em casais (Dissertação de Mestrado). Programa de Pós-Graduação em Psicologia, Universidade Federal do Rio Grande do Sul, Rio Grande do Sul, Brasil.

Delatorre, M. Z., \& Wagner, A. (2015). Estratégias de resolução de conflitos conjugais: evidências de validade do CRBQ. Avaliação Psicológica, 14(2), 233 242. doi: 10.15689/ap.2015.1402.08.

Delatorre, M. Z., Scheeren, P., \& Wagner, A. (2017). Conflito conjugal: Evidências de validade de uma escala de resolução de conflitos em casais do sul do Brasil. Avances en Psicologia Latinoamericana, 35(1), 79-94. doi:10.12804/revistas.urosario.edu. co/apl/a.3742.

Feist, J., Feist, J. G., \& Roberts, T. (2015). Teorias da Personalidade. $8^{\mathrm{a}}$ ed. São Paulo: AMGH Editora Ltda.

Fellows, K. J., Chiu, H. Y., Hill, E. J., \& Hawkins, A. J. (2015). Work-Family Conflict and Couple Relationship Quality: A Meta-analytic Study. Journal of Family and Economic Issues, 37(4), 509-518. Doi:10.1007/s10834-015-9450-7.

Fincham, F. D. (2003). Marital conflict: Correlates, structure, and context. Current Directions in Psychological Science, 12(1), 23-27. Doi:10.1111/1467-8721.01215

Flora, J., \& Segrin, C. (2015). Family conflict and communication. In L. H. Turner, \& R. West (Eds.), The SAGE handbook of family communication (pp.91-106). Thousand Oaks: Sage.

Gottman, J. M. (1994). Why marriages succeed or fail: And bow you can make yours last. New York: Simon \& Schuster.

Gottman, J. M., \& Notarius, C. I. (2000). Decade review: Observing marital interaction. Journal of Marriage \& The Family, 62(4), 927-947.

Psico-USF, Bragança Paulista, v. 26, n. 3, p. 483-493, jul./set. 2021 
Greeff, A.P., \& Bruyne, T. (2000). Conflict management style and marital satisfaction. Journal of Sex \& Marital Therapy, 26(1), 321-334.

Gunkel, M., Schlaegel, C., \& Taras, V. (2016). Cultural values, emotional intelligence, and conflict handling styles: A global study. Journal of World Business, 51(4), 568-585. doi:10.1016/j.jwb.2016.02.001.

Horn, J. L. (1965). A rationale and test for the number of factors in factor analysis. Psychometrika, 30(1), 179-185. doi: 10.1007/BF02289447.

Igbo, H. I., Grace, A. R., \& Christiana, E. O. (2015). Relationship between Duration of Marriage, Personality Trait, Gender and Conflict Resolution Strategies of Spouses. Procedia - Social and Behavioral Sciences, 190(1), 490-496. doi:10.1016/j. sbspro.2015.05.032.

Iveniuk, J., Waite, L. J., Laumann, E., McClintock, M. K. \& Tiedt, A. D. (2014). Marital Conflict in Older Couples: Positivity, Personality and Health. Journal of Marriage and Family, 76(1), 130-144. doi: 10.1111/jomf.12085

John, O. P., Donahue, E. M., \& Kentle, R. L. (1991). The "Big Five" Inventory-Versions $4 a$ and 54. Berkeley, University of California. Institute of Personality and Social Research.

Kim, J. S., Weisberg, Y. J., Simpson, J. A., Oriña, M. M., Farrell, A. K., \& Johnson, W. F. (2015). Ruining it for Both of Us: The Disruptive Role of Low-Trust Partners on Conflict Resolution in Romantic Relationships. Social Cognition, 33(5), 520-542. doi:10.1521/soco.2015.33.5.520

Kurdek, L. (1994). Conflict Resolution Styles in Gay, Lesbian, Heterosexual Nonparent, and Heterosexual Parent Couples. Journal of Marriage and Family, 56(3), 705-722. doi:10.2307/352880.

McNulty, J. K. (2008). Neuroticism and interpersonal negativity: the independent contributions of perceptions and behaviors. Personality and Social Psychology Bulletin, 34(11), 1439-1450.

Milfont, T. L., \& Fischer, R. (2010). Testing measurement invariance across groups: Applications in cross-cultural research. International Journal of Psychological Research, 3, 111-121.

Nunes, C. H. S. S. Hutz, C. S. \& Nunes, M. F. O. (2010). Bateria Fatorial de Personalidade (BFP): Manual técnico. São Paulo: Casa do Psicólogo.
Nunes, C. H. S. S., \& Primi, R. (2010). Aspectos técnicos e conceituais da ficha de avaliação dos testes psicológicos. In Conselho Federal de Psicologia, Avaliação psicológica: diretrizes na regulamentação da profissão, (pp. 101-128). Brasília: Conselho Federal de Psicologia.

Ogolsky, B. G., Monk, J. K., Rice, T. M., Theisen, J. C., \& Maniotes, C. R. (2017). Relationship Maintenance: A Review of Research on Romantic Relationships. Journal of Family Theory \& Review, 9(3), 275-306. doi:10.1111/jftr.12205.

Ozer, D. J., \& Benet-Martinez, V. (2006). Personality and the prediction of consequential outcomes. Annual Review of Psychology, 57(1), 401-421. doi: 10.1146/ annurev.psych.57.102904.190127

Pasquali, L. (2011). Psicometria: teoria dos testes na psicologia e na educação. Petrópolis, RJ: Vozes.

Rands, M, Levinger, G., \& Mellinger, G. D. (1981). Patterns of conflict resolution and marital satisfaction. Journal of Family Issues, 2(3), 297- 231. doi: 10.1177/0192513X8100200303.

Reese-Weber \& Bartle-Haring, S. (1998). Conflict resolution styles in Family subsystems and adolescent romantic relationships. Journal of Youth and Adolescence, 27(6), 735-752.

Rubenstein, J. L., \& Feldman, S. S. (1993). Conflict-resolution behavior in adolescent boys: Antecedents and adaptational correlates. Journal of Research on Adolescence, 3(1), 41-66. doi: 10.1207/ s15327795jra0301_3.

Schmitt, D. P., Allik, J., McCrae, R. R., Benet-Martinez, V., Alcalay, L., Ault, L. et al. (2007). The geographic distribution of big five personality traits: Patterns and profiles of human self-description across 56 nations. Journal of CrossCultural Psychology, 38(2), 173-212.

Sierau, S., \& Herzberg, P. Y. (2012). Conflict resolution as a dyadic mediator: considering the partner perspective on conflict resolution. European Journal of Personality, 26(3), 221-232. doi.org/10.1002/ per. 828

Straus, M. A., Hamby, S. L., Boney-McCoy, S., \& Sugarman, D. B. (1996). The Revised Conflict Tactics Scale (CTS2): Development and preliminary psychometric data. Journal of Family Issues, 17(3), 283-316. doi:10.1177/019251396017003001. 
Urbina, S. (2007). Fundamentos da testagem psicologica. Porto Alegre, RS: Artmed.

Van de Bongardt, D., Yu, R., Dekovic, M., \& Meeus, W. H. J. (2015). Romantic relationships and sexuality in adolescence and young adulthood: The role of parents, peers, and partners. European Journal of Developmental Psychology, 12, 497-15. Doi:10.1080/174 05629.2015.1068689.
Zacchilli, T. L., Hendrick, C., \& Hendrick, S. S. (2009). The romantic partner conflict scale: A new scale to measure relationship conflict. Journal of Social and Personal Relationships, 26(8), 1073-1096. doi:10.1177/0265407509347936.

Recebido em: 17/07/2019

Reformulado em: 25/05/2020

Aprovado em: 24/08/2020 
Acknowledgments:

Agradecimento ao apoio financeiro da Coordenação de Aperfeiçoamento de Pessoal de Nível Superior (CAPES)

About the authors:

Patrícia Nunes da Fonseca é Doutora em Psicologia Social pela Universidade Federal da Paraíba, Professor do departamento de Psicologia da Universidade Federal da Paraíba e da Pós-Graduação de Psicologia Social.

ORCID: http://orcid.org/0000-0002-6322-6336

E-mail:pnfonseca.ufpb@gmail.com

Nájila Bianca Campos Freitas é Doutoranda do Programa de Pós-Graduação em Psicologia Social, da Universidade Federal da Paraíba. Mestra em Psicologia Social, com formação em Psicopedagogia Clínica e Institucional. ORCID: https://orcid.org/0000-0003-3371-570X

E-mail: najila.bianca@hotmail.com

Ricardo Neves Couto é Doutor em Psicologia Social pela Universidade Federal da Paraíba, Professor do departamento de Psicologia da Universidade Federal do Piauí e da Universidade Regional da Bahia-UNIRB, Campus Parnaíba. ORCID: http://orcid.org/0000-0001-9989-4857

E-mail: r.nevescouto@gmail.com

Jérssia Laís Fonseca dos Santos é Doutoranda do Programa de Pós-Graduação em Psicologia Social, da Universidade Federal da Paraíba. Mestre em Psicologia Social e Psicopedagoga Clínica e Institucional.

ORCID: https://orcid.org/0000-0002-3743-7877

E-mail: jerssyafonseca@hotmail.com

Viviany Silva Araújo Pessoa é Doutora em Psicologia Social pela Universidade Federal da Paraíba, Professor do departamento de Psicopedagogia da Universidade Federal da Paraíba.

ORCID: https://orcid.org/0000-0002-4822-587X

E-mail: viviany.pessoa@gmail.com

Contact:

Universidade Federal da Paraíba - UFPB

Rua Campus I - Lot. Cidade Universitária, setor CCHLA

João Pessoa-PB, Brasil

CEP: 58033-455

Telefones: (83) 9 87174928/3216-7330 
